\title{
Perception of the Urban Dwellers on the Solid Waste Management in Agartala City, India
}

\author{
Abhijit Santra $^{1 *}$, Debasish Debbarma ${ }^{1}$, Saptarshi Mitra ${ }^{2}$ \\ ${ }^{1}$ Research Scholar, ${ }^{2}$ Assistant Professor, Department of Geography and Disaster Management, Tripura \\ University, India
}

\begin{abstract}
The implementation of Solid Waste Management (SWM) facility to the every corner of the city is a challenge to the Municipal Corporation because without proper routine wise collection, disposal and awareness about Municipal Solid Waste (MSW), it is difficult to build up and maintain SWM of Agartala City. The two main Rivers Haora and Kata Khal are passing through the heart of Agartala City. The slum areas and markets (Battala and Lake Chowmuhani) developed adjacent to the rivers. The present paper is aims to assess the condition of municipal solid waste disposal system of Agartala City. The questionnaire survey has been carried out for understanding the people perception regarding the SWM, the awareness regarding degradation of river health and open field dumping. The perception of people and photographic evidences reveal that rivers are used as a dumping ground in some areas. Even open field dumping is also practice in the comparatively developed areas in city which shows lack of awareness of the common people. For maintaining clean and green environment of Agartala City the government and the people have to work jointly otherwise, open field dumping and degradation of river health will be a threat to the livelihood of urban dwellers.
\end{abstract}

Key words: Municipal solid waste, Questionnaire, Solid waste management, Solid waste disposal.

\section{INTRODUCTION}

The proper management of Municipal Solid Waste (MSW) is one of the key indicators of the quality of urban livelihood of the city. MSW generation in terms of $\mathrm{kg} / \mathrm{capita} /$ day has a positive correlation with economic development. Due to rapid industrialization and rural urban migration, urban growth of population has been increasing rapidly in cities. The MSW amount is expected to increase significantly in the near future as the country strives to attain an industrialized nation status by the year 2020 (Shekdar et al., 1992; CPCB, 2004; Sharholy et al., 2008). Some of the works of Mato et al. (1994), Oke and Awofeso (2006), Syed (2006), Aljaradin and Persson (2012), Joel (2013), Mrówczyńska (2014), Santra et al. (2014) provide different dimensions on the issues related to the pattern and generation of solid waste, its disposal and the related phenomenon. Xiao et al. (2007) mentioned that the rapid economic growth and increasing population within the urban area generate huge amount of solid waste. The extension of Solid Waste Management facility in every corner of city is a challenge to the corporation because without proper awareness, routine collection and disposal of solid waste, cannot build up and maintain Agartala City as a "clean city". The city has developed adjacent to Rivers Haora and Kata Khal. The waste materials are directly dumped on the open road side, inland water body and the river which causes unhealthy environment of the city as well as deteriorate the river water also (Santra et al., 2017). The major issue is related to eco-environment which raises the question if urban dwellers are concern about the river health or not. The objective of present study is to identify the awareness level of the people of the city and also the opinion of people about the Municipal Solid Waste Management (MSWM) of Agartala City.

\section{STUDY AREA}

Agartala City is one of tiny rapid upgrading city of Tripura located at the extreme western part of the state touching International Border of Bangladesh. The latitudinal and longitudinal extension of the city is $23^{\circ} 45^{\prime} \mathrm{N}$ to $23^{\circ} 55^{\prime} \mathrm{N}$ and $91^{\circ} 15^{\prime} \mathrm{E}$ to $91^{\circ} 20^{\prime} \mathrm{E}$. The city is the centre for commerce, education and administration unit of the state. The Agartala Municipal Corporation (AMC) is broadly divided into four planning zones like North, East, Central and South (JNNURM, 2006). The city has developed in the flood plain of the Rivers Haora and Kata Khal (man-made canal) with an area $76 \mathrm{~km}^{2}$. City Sanitation Plan Agartala, 2010 reveals that in the year 2001, the population of AMC was about 1,89,998 and MSW generation was 77 MT/day and in 2004 the total population increased to 3,68,493 and the MSW generation was $198 \mathrm{MT} / \mathrm{day}$. In the year 2011 the population increased to 4,00,004 and the MSW generation increased to $250 \mathrm{MT} /$ day. 


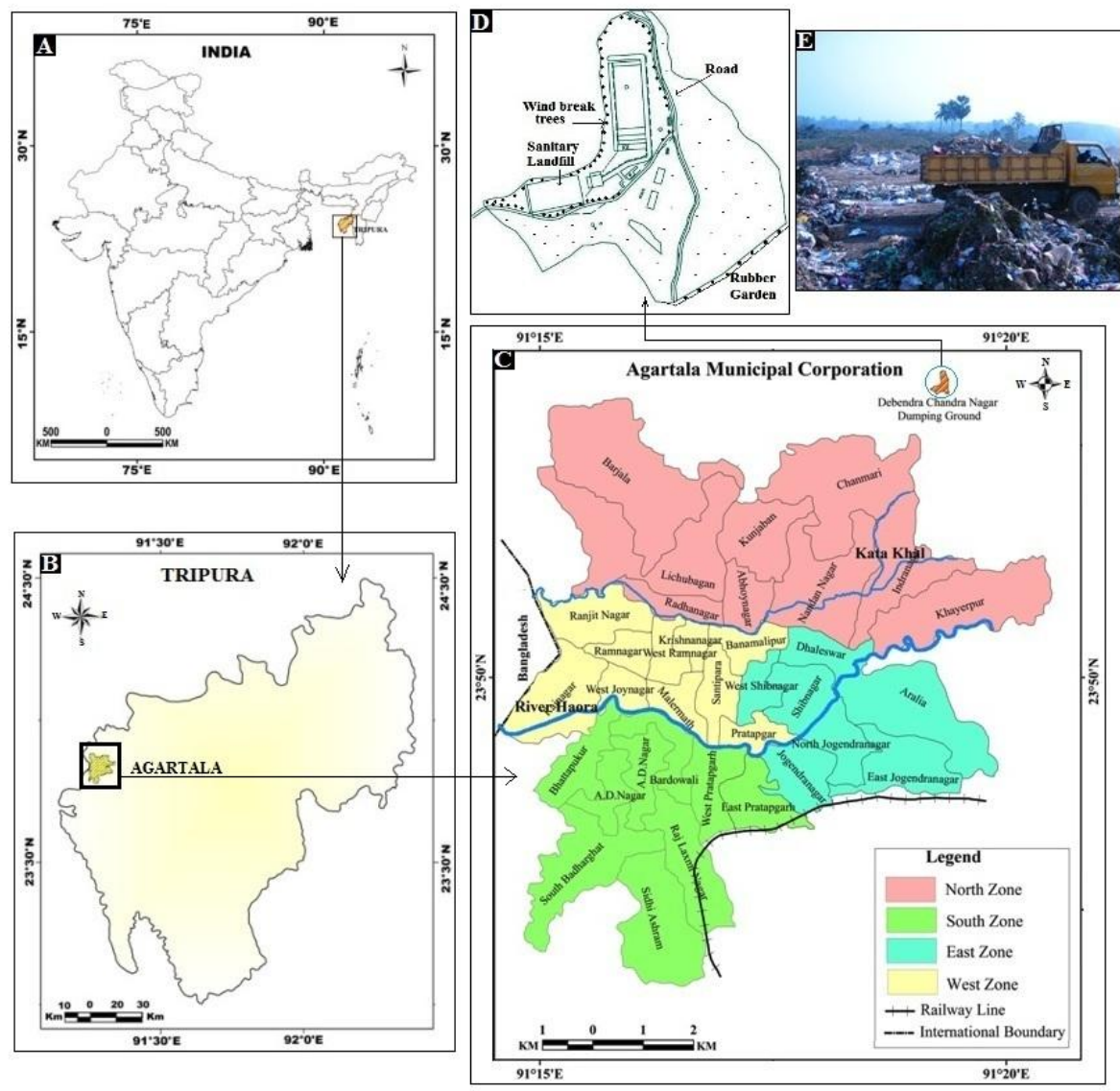

Fig.1. Location map of the Agartala Municipal Corporation area (C) and the lay out map of the present dumping ground (D).

\section{METHODOLOGY}

The methodology of the work has been carried out through cartographic techniques, statistical methods and questionnaire survey. The reconnaissance survey has been done to identify the present problem. The base map has been prepared with the help of settlement map and Google earth image. Primary data have been collected through household questionnaire survey and secondary data regarding solid waste generation, collection and disposal system were collected from office of the Agartala Municipal Corporation. The direct interview (door-to-door) has been carried out randomly selecting a total number of 945 households from all the wards of AMC. The collected data has been tabulated and calculated using statistical methods and represented by different maps with the help of Arc GIS 9.8 software. Handheld GPS (Global Positioning System) has been used for identification of the open field dumping along road side and rivers.

\subsection{Generation of solid waste}

\section{RESULT AND DISCUSSION}

The major source of MSW in the AMC area are household, market, road side and commercial waste. Agartala City generates 250 MT/day i.e., $0.649 \mathrm{~kg} /$ capita/day MSW (Table 1). Highest amount of solid waste (125 MT/day) has generated from sweeping roads. $60 \mathrm{MT} /$ day waste are generated in fish market, vegetable market etc. $30 \mathrm{MT} /$ day waste are generated from commercial sectors (hotel/shops/institutions) and $20 \mathrm{MT} / \mathrm{day}$ waste are generated from door to door collection of household waste.

Table 1: Municipal Solid Waste Generation (Category-wise), Agartala City

\begin{tabular}{|l|c|}
\hline \multicolumn{1}{|c|}{ Waste Generated Sources } & Quantity (in MT/per day) \\
\hline Household waste/ Kitchen Waste (door to door collection) & 20 \\
\hline Vegetable Markets, Fish Markets, Mandir etc. & 60 \\
\hline Workshops/Garages/Electronic waste & 4.5 \\
\hline Commercial waste (hotels/shops/institutions) & 30 \\
\hline Dead Animals/Carcasses & 0.5 \\
\hline Waste thrown on roads collected by Sweeping & 125 \\
\hline Drain silt & 10 \\
\hline Total Solid Waste Generation & 250 MT/Day \\
\hline
\end{tabular}

Source: AMC, 2011 


\subsection{AMC waste collection and disposal process}

AMC has introduced a swift transport system for disposal of the waste materials from the central zone of the city. The solid waste disposal process follows three steps: collection, transportation and disposal to dumping ground. The primary waste materials collection is started by street sweepers. They collect waste materials from the roads which are dumped to the nearest road side metallic community bins. The primary collected MSW are initially stored on the road side community bin or at an open space. Total 601 numbers of metallic community bins (small and big size) have been provided by AMC, among which 535 numbers of small bin with capacity $1.1 \mathrm{~m}^{3}$ and 66 numbers of big community bin with capacity $4.5 \mathrm{~m}^{3}$ were placed along the road side all over the city (Fig. 2A). Around 20 numbers of NGOs are collecting the household waste from door-todoor over the city with Rs. 30/month/household. Hotels, restaurants and other commercial sectors are covered by one NGO and the wastage of all the market areas are collected by 10 numbers of NGOs with fixed charge of Rs. 250/month. The secondary collection of garbage are kept in the small (capacity $1.1 \mathrm{~m}^{3}$ ) and big (capacity 4.5 $\mathrm{m}^{3}$ ) containers provided by AMC and open space or road side dumping place over the city (Santra et al,. 2014). The accumulated waste are finally collected by the dumper placer vehicles or tripper truck for transporting the waste to the dumping ground or disposal ground (Debendra Chandra Nagar) which is $12 \mathrm{~km}$ away from Agartala City (Fig. 2B).

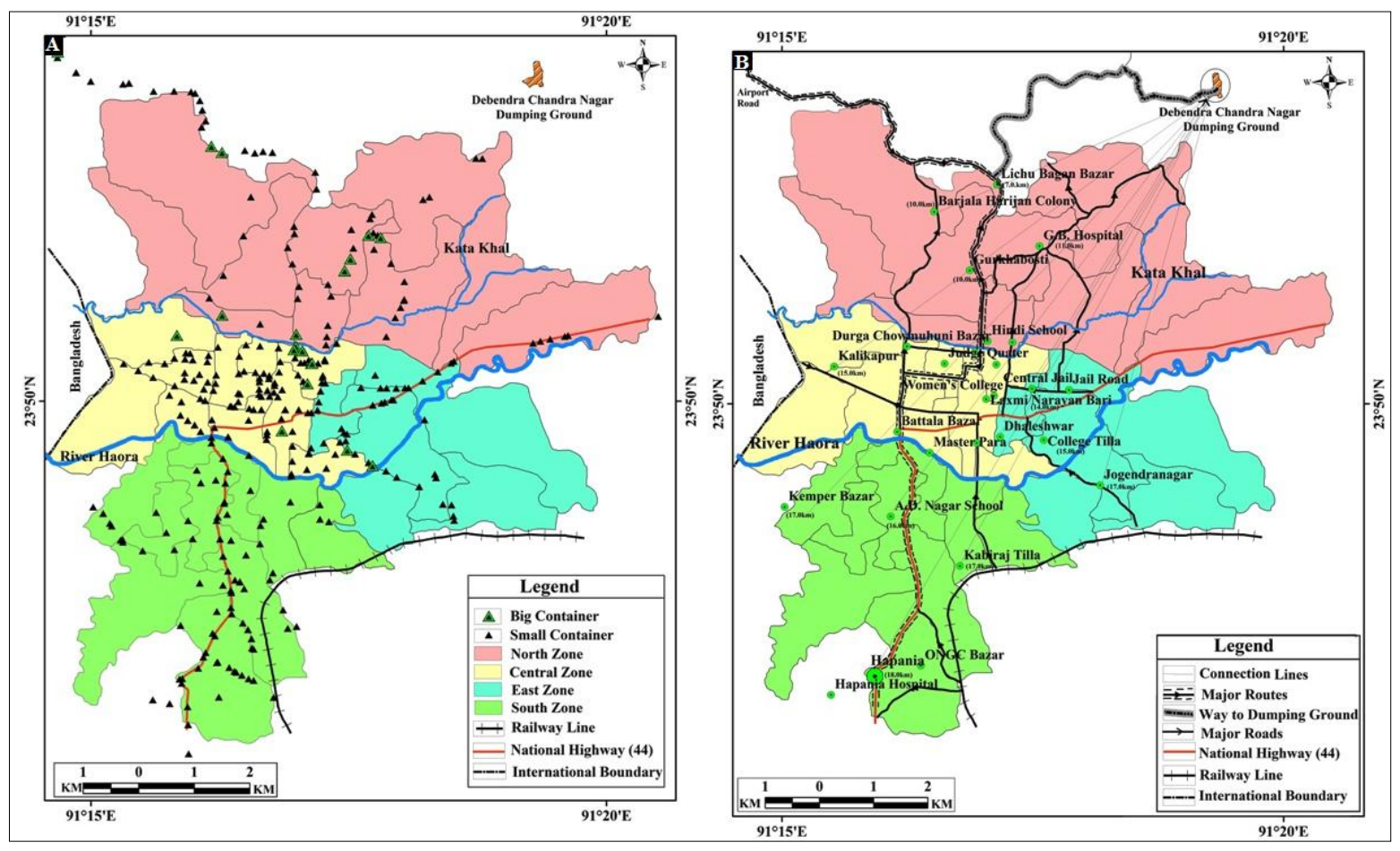

Fig. 2. (A) Zone wise distribution of solid waste containers (small and big size) (B) Waste Disposal flow map of Agartala City, 2014

\subsection{Unscientific dumping of the solid waste}

Primary dumping place for the urban dwellers are mostly on road side, over the drain, bank of river, marshy land and water body. The slums occupy along the banks of the Rivers Haora and Kata Khal and for the slum-dwellers river bank is the major dumping place. The people of Ramnagar, Orient Chowmuhani, Krishnanagar, Dhaleswar area also dump the solid waste over the road side instead of present metallic containers. In some cases the people dump household waste over the nearest water body and marshy lands. The photographic evidences indicate that out-let of drains are directly connected with the rivers. Huge amounts of urban solid waste are dumped to the river (Fig. 3).

Photographs of fig. 3.A, B, C, D represent all the out lets are directly connected with the River Haora and photograph E, F are showing the condition of Kata Khal. Photograph G, H, I showing the road side heap of garbage and $\mathrm{J}$ represent the dumping near pond side. Photograph $\mathrm{K}$ represent garbage is dumped near wall and $\mathrm{L}$ is the land filling site of Ramnagar area, is the planning area of the city. 

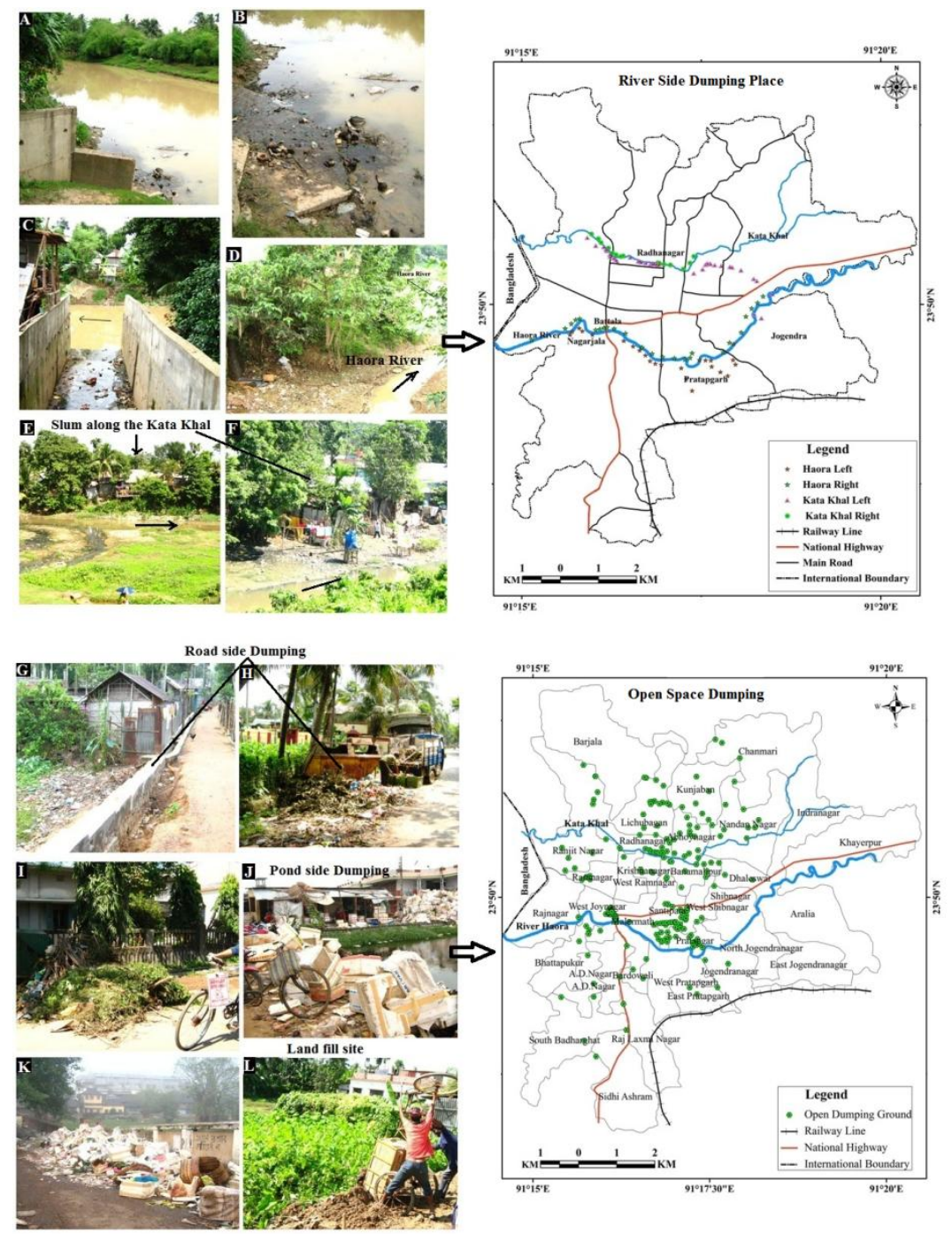

Fig. 3. The photographs and maps represent dumping along the rivers (A, B, C, D, E, F) and open field dumping along the road (G, H, I, K), pond side (J), marshy land in Ramnagar (L).

\section{PERCEPTION ANALYSIS}

5.1 Types of solid waste

Urban Solid wastes are categorized into four parts such as household waste, industrial waste, medical waste and business waste (Fig. 4.A). Maximum number of people responded that household waste is particularly larger in volume (84 per cent) than other types of waste within the city. The medical waste is 12 per cent and rest 4 per cent are business waste. Industrial waste is nil due to non-existence of major industry within the city.

\subsection{Household waste}

The fig. 4.B represents the different types of household waste. The highest number of people ( 82 per cent) dumps combined waste such as vegetables, cloths, plastics etc. Whereas, 16 per cent dump non-disposable materials such as medical waste, glasses etc. and 2 per cent dumped disposable waste (vegetable) which easily dissolves in soil.

\subsection{Open dumping places of household waste}

The fig.4.C indicates four types of dumping places such as open land, drain, roadside and dustbin. 33 per cent of the houses dump their waste materials on the roadside because AMC has not provided sufficient container. The interaction with people reveals that they are lethargic to carry household waste to the community bin which is located far from their house. In some places AMC has not yet provide any metallic container. 26 per cent houses dump waste materials in the drains because AMC does not collect waste material regularly. Rest 23 per cent dump on the open space, fallow land and only 18 per cent houses are using dustbin. The survey reveals lack of awareness of common people regarding SWM. The fig. 4.D represents the dumping of waste 
materials on land which is divided into three parts i.e. dumping in own land, dumping in public land and dumping on fallow or waste land. 79 per cent people responded that they dump the waste materials on public land like road side, drain, river banks, khal, pond side etc. and 21 per cent of the people dump household waste on fallow or waste land. Nobody has responded to keep the household waste within their own land.
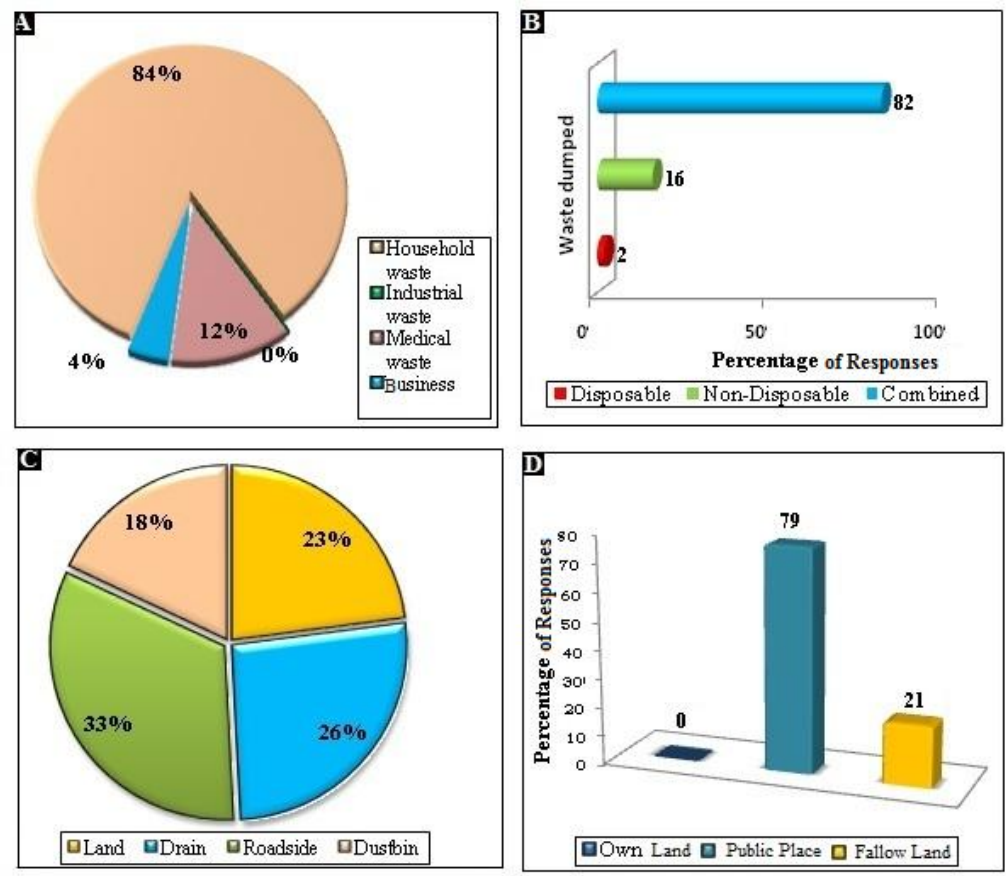

Fig. 4. Types of solid waste (A), Different types of waster in terms of disposal, non-disposable and combine waste dump (B), Open field dumping places (C), Dumping of solid waste in different types of lands (D) in

\subsection{Time Schedule}

Agartala City.

The time schedule of garbage collection from different urban areas in AMC is divided into three parts such as morning (6:00 AM-12:00 PM), noon (12:00 PM-3:00 PM) and afternoon (3:00PM-6:00PM) (Fig. 5.A). 52 per cent people responded that the AMC does not collect garbage in schedule time. 40 per cent people replied that garbage collection is mostly done in the morning and rest 8 per cent responded that it is done in the afternoon.

\subsection{Collection of waste material in term of daily/ weekly/ monthly}

Fig. 5.B represents that 8 percent people responds that waste material is collected daily from their houses. 60 per cent respondents in the areas like Ramnagar and Krishnanagar said that garbage is collected in alternate days i.e. three or four times in a week. 20 per cent respondents replied that the garbage is collected monthly and 12 per cent did not respond.
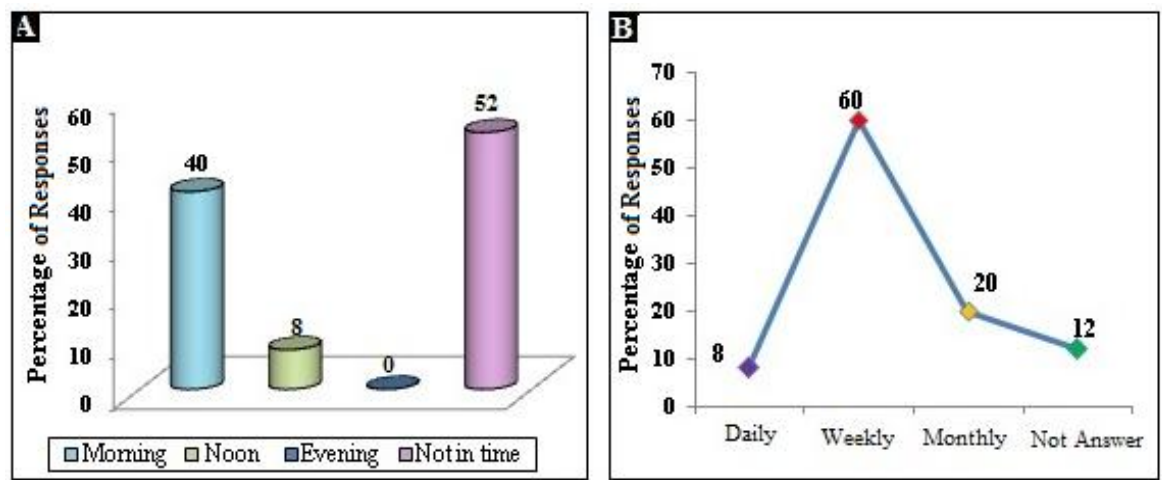

Fig. 5. (A) Represent Time schedule of waste collection (morning, noon, evening) and (B) represents the collection of waste in terms of Daily/ Weekly/ Monthly. 
6.1 Types of problem

\section{NATURE OF PROBLEMS}

The fig. 6.A shows the different kinds of problems which occur in many areas of the city. The majority of respondents (42 per cent) said that water logging is the main problem in Ramnagar, Orient Chowmuhani, Motor stand etc. 28 per cent respondents said about health problem. About 25 per cent alleged about the problem of mosquitoes and 6 per cent did not give any answer.

\subsection{Blockage of sewerage system and water logging}

Fig. 6.B shows that 82 per cent respondents reported about the blockage of sewerage system and 18 per cent did not agree with the statement. The majority of the people admitting about water logging which gives birth to several diseases such as, viral fever, Malaria and skin infection. The people residing in Ramnagar, Krishnanagar, College Tilla and the banks of the Rivers Haora and Kata Khal are facing this problem. Other than this, dengue, typhoid and diarrhea are also the common diseases in this area. People informed that AMC rarely provide the mosquito killing spray in this locality.
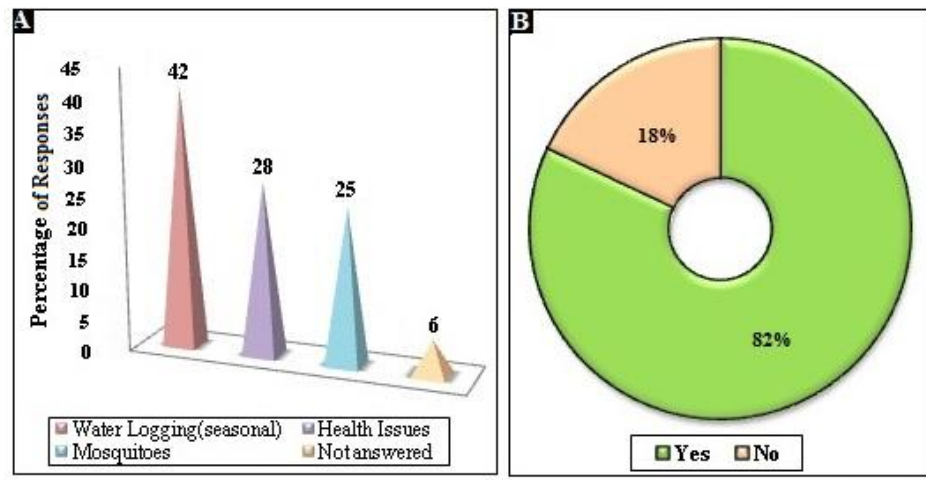

Fig. 6. (A) Represent the kind of problems that urban dwellers have experiences and (B) shows the variation of perception among the urban dwellers on blockage of sewerage system.

\section{CONCLUSION}

The survey reveals that the waste material from Battala market and Lake Chowmuhani market are directly dumped in the Rivers Haora and Kata Khal. Along these two rivers several outlet or drains are directly linked with rivers. The Kata Khal is also used as an open sanitation area by people living in slum area. They are also not getting any facility like public washroom (sulabh sauchalaya/toilet) or SWM from AMC. As a result, rivers are used as the only dumping ground by them. This is very serious threat to the river health and urban environment. The people who are living in Ramnagar, Krishnanagar and Dhaleswar area, does not have any temporary dumping place in their houses. The people also feel lethargic to carry and dump house-hold waste from their own house to the road side community bin. As a result, heap of solid waste is observed on many lanes, pond side within central zone of the city. The interaction with the common people, officers of AMC and field observation reveals that AMC has already taken significant steps for SWM of Agartala City. Rehabilitation of slum people and establishment of waste material treatment plant at Debendra Chandra Nagar prove to be positive steps towards better livelihood of urban dwellers. The present research propose two main aspects for solid waste management i.e. active participation of common people through proper awareness and timely collection and disposal of solid waste from the primary and secondary dumping places.

\section{ACKNOWLEDGEMENT}

The authors are glad to acknowledge sincere co-operation of the officers of Agartala Municipal Corporation for valuable interaction.

\section{REFERENCES}

[1] Aljaradin, M., \& Persson, K. M., Environmental impact of municipal solid waste landfills in semi-arid climates-case study-Jordan, The Open Waste Management Journal 5, no. 1, 2012, 28-39.

[2] Central Pollution Control Board (CPCB), Management of Municipal Solid Waste, Ministry of Environment and Forests, New Delhi, India, 2004.

[3] City Sanitation Plan, Tripura, Draft Report Agartala, Ministry of Urban Development, Govt. of India, 2010.

[4] Jawaharlal Nehru National Urban Renewal Mission (JNNURM), City development plan-Agartala, LEA Associates South Asia Pvt. Ltd., New Delhi in association with CEPT, Ahmadabad, 2006. 
[5] Joel, A. B., \& Fansen, T., Pattern and disposal methods of municipal waste generation in Kaduna metropolis of Kaduna state, Nigeria, International Journal of Education and Research, l (12), 2013, 1-14.

[6] Mato, S., D. Otero, and M. Garcia, Composting of $<100 \mathrm{~mm}$ fraction of municipal solid waste, Waste management \& research 12, no. 4, 1994, 315-325.

[7] Mrówczyńska, B., Route planning of separate waste collection on a small settlement, Transport Problems 9, no. 1, 2014, 61-68.

[8] Oke, S. A., \& Awofeso, K. O., A factorial analysis experimentation of inappropriate waste disposal, Journal of Environmental Health Science \& Engineering 3, no. 2, 2006, 123-132.

[9] Santra, A., Debbarma, D., Sen S., \& Mitra, S., Municipal Solid Waste Management System in Agartala City, Tripura, India. "Hill Geographer 14, no. 2, 2014, 37-49.

[10] Santra, A., Mitra. S., \& Debbarma, D., Urbanization, Land use and Emerging Issues of Agartala City, India. Researchers World 8. no 2, 2017, 26-35.

[11] Sharholy, M., Ahmad, K., Mahmood, G., \& Trivedi, R. C., Municipal solid waste management in Indian cities-A review." Waste management 28, no. 2, 2008, 459-467.

[12] Shekdar, A. V., K. N. Krishnaswamy, V. G. Tikekar, and A. D. Bhide, Indian urban solid waste management systems-jaded systems in need of resource augmentation." Waste management 12, no. 4, 1992, 379-387.

[13] Syed, S, Solid and liquid waste management." Emirates journal for engineering research 11, no. 2, 2006, 19-36.

[14] Xiao, Y., Bai, X., Ouyang, Z., Zheng, H., \& Xing, F., The composition, trend and impact of urban solid waste in Beijing." Environmental Monitoring and Assessment 135, no. 1, 2007, 21-30. 